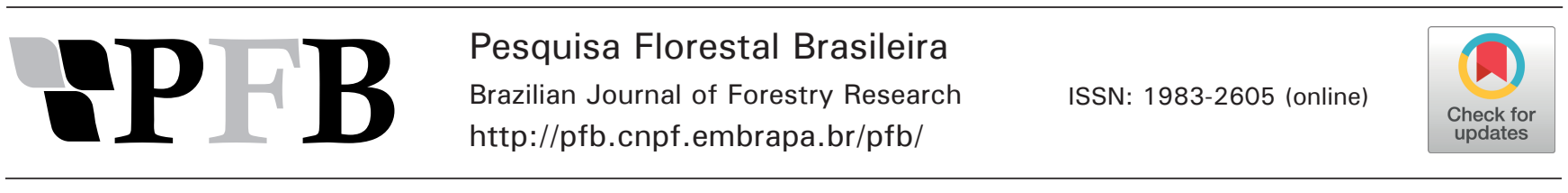

\title{
In vitro seed germination and multiplication of Calophyllum brasiliense
}

\author{
Sheila Susy Silveira ${ }^{*}$, Juliana Degenhardt-Goldbach², Marguerite Quoirin ${ }^{2}$ \\ ${ }^{1}$ Universidade Federal do Paraná, Departamento de Botânica, Av. Coronel Francisco Heráclito dos Santos, s/n., CEP 81530-900, Curitiba, PR, Brasil \\ ${ }^{2}$ Embrapa Florestas, Estrada da Ribeira, Km 111, C P 319, CEP 83411-000, Colombo, PR, Brasil
}

*Autor correspondente:

sheila.susy@gmail.com

Index terms:

Gibberellic acid

Benzylaminopurine

Germination speed index

Termos para indexação:

Ácido giberélico

Benzilaminopurina

Índice de velocidade de germinação

\section{Histórico do artigo:}

Recebido em 01/03/2016

Aprovado em 23/08/2016

Publicado em 30/09/2016

doi: 10.4336/2016.pfb.36.87.1168

\begin{abstract}
Calophyllum brasiliense is a tree species with limited natural reproduction. In vitro germination may be an alternative for obtaining high-quality seedlings. Seeds were maintained in water before surface disinfestation and compared with control seeds (i.e. not immersed), without differences between treatments. $\mathrm{HgCl}_{2}$ used during surface-disinfestation reduced contamination rates of cultures. Fungal contamination was reduced with fungicide added to culture medium ( 23 to $6.4 \%$ ), although bacterial contamination increased ( 24 to $36 \%$ ). In another experiment, seeds were immersed in plant preservative mixture ( $\mathrm{PPM}^{\mathrm{TM}}$ ) prior to surface disinfestation. By combining immersion for $48 \mathrm{~h}$ and $2 \mathrm{~mL} \mathrm{~L}^{-1}$ in culture medium, contamination was only $6 \%$. Seeds immersion in $\mathrm{GA}_{3}$ prior to surface disinfestation reduced root formation as concentration increased. Germination rate and GSI were reduced, respectively, from $72 \%$ and 0.129 ( $24 \mathrm{~h}$ ) to $60 \%$ and $0.092\left(48 \mathrm{~h}\right.$ ) according to exposure time to $\mathrm{GA}_{3}$. After 90 days in multiplication medium containing benzylaminopurine, average number of shoots per nodal segment was 3.4. In conclusion, in vitro germination of $C$. brasiliense seeds is feasible in sucrose-free WPM medium and reaches a high contamination-free rate (up to $93.3 \%$ ).
\end{abstract}

\section{Germinação in vitro de sementes e multiplicação de Calophyllum brasiliense}

\begin{abstract}
Resumo - Calophyllum brasiliense é uma espécie arbórea com sistema de propagação natural limitada. A germinação in vitro pode ser uma alternativa para obtenção de plântulas de qualidade. Sementes foram mantidas em água antes da desinfestação e comparadas com sementes controle (não imersas), sem diferença entre os tratamentos. $\mathrm{HgCl}_{2}$ usado durante a desinfestação reduziu a contaminação das culturas. A contaminação fúngica foi reduzida com fungicida adicionado ao meio (23 para 6,4\%), mas a porcentagem de bactérias foi aumentada ( 24 para $36 \%$ ). Em outro experimento, as sementes foram imersas em plant preservative mixture (PPM $\left.{ }^{\mathrm{TM}}\right)$ antes da desinfestação. Combinando a imersão por $48 \mathrm{~h} \mathrm{e} 2 \mathrm{~mL} \mathrm{~L}^{-1}$ no meio de cultura, a contaminação foi de $6 \%$. A imersão das sementes em $\mathrm{GA}_{3}$ antes da desinfestação reduziu a formação de raízes conforme a concentração foi aumentada. A germinação e o IVG foram reduzidos, respectivamente, de $72 \%$ e 0,129 (24 h) para $60 \%$ e 0,092 (48 h), de acordo com o tempo de exposição a GA . Após 90 dias em meio de multiplicação contendo benzilaminopurina, o número médio de brotações por segmento nodal foi 3,4. A germinação in vitro de C. brasiliense é viável em meio WPM sem sacarose, com até 93,3\% de sobrevivência.
\end{abstract}

\section{Introduction}

Calophyllum brasiliense Cambess. (Clusiaceae), known in Brazil as guanandi, jacareuba or olandi, is a tree species native to tropical America, common in rainforests and humid soils, tolerant to hypoxia (Marques \& Joly, 2000; Oliveira \& Joly, 2010). This species is economically important due to the good quality of its wood (Cole et al., 2011), to its use for reforestation (Cole et al., 2011) and to its medicinal properties (Ito et al., 2002; Souza et al., 2009), including anti-HIV potential (Huerta-Reyes et al., 2004; Bernabé-Antonio et al., 2010). 
Guanandi reproduction occurs at irregular intervals and its establishment rate is low, due to grazing and environmental conditions (Newstrom et al., 1994; Fischer \& Santos, 2001; King, 2003; Cole et al., 2011). Their seeds are recalcitrant and therefore their storage time is limited (Cole et al., 2011).

Tissue culture is an alternative for producing highquality seedlings and in vitro germination can be applied as in the case of Calophyllum inophyllum (Thengane et al., 2006), specially for selected seeds resulting from breeding programs, which usually produce few plant material which could be clonally propagated. However, contamination rates and specific culture conditions for multiplication of $C$. brasiliense are still unknown.

Contaminants such as fungi and bacteria often lead to losses during in vitro culture of plants, therefore surface disinfestation of seeds is necessary (Leifert et al., 1991; Mng'Omba et al., 2011). It can be performed by using a number of compounds such as calcium and sodium hypochlorite, mercury chloride, antibiotics and fungicides (Mng'Omba et al., 2011). Concentrations and exposure times for different chemicals varies depending on explants type (Leifert et al., 1991). A fungicide was used before disinfestation of $C$. inophyllum seeds (Thengane et al., 2006) and for the same species and C. apetalum, mercury chloride was applied to seeds (Nair \& Seeni, 2003; Thengane et al., 2006), showing effective results.

Gibberellic acid plays a known role during seed germination, acting in breakage of aleurone layer and increasing oxygen uptake by embryos (Bewley et al., 2013). For species such as Cicer arietinum (Kaur et al., 1998), Capparis ovata (Soyler \& Khawar, 2007) and C. spinosa (Arefi et al., 2012), the addition of this plant regulator increases germination rates.

A cytokinin is used to promote shoot multiplication in most cultures. For both C. inophyllum (Thengane et al., 2006) and C. apetalum (Nair \& Seeni, 2003), 6-benzylaminopurine (BAP) was added to the culture medium resulting in multiple shoots formation in concentrations up to $44 \mu \mathrm{M}$.

The aim of this study was to determine the best surface disinfestation method for in vitro establishment and germination of guanandi seeds and in vitro multiplication from nodal segments.

\section{Material and methods}

\section{Plant material and culture medium}

Mature fruits of Calophyllum brasiliense were obtained from Instituto Brasileiro de Florestas (IBF) and were unpulped manually. After removing the tegument with a knife, the seeds were submitted to different disinfestation treatments and culture conditions (Figure 1a). The standard culture medium was WPM (Lloyd \& McCown, 1980) without plant growth regulators (PGRs) supplemented with $30 \mathrm{~g} \mathrm{~L}^{-1}$ sucrose and $6 \mathrm{~g} \mathrm{~L}^{-1}$ agar (Vetec ${ }^{\circledR}$, Rio de Janeiro, Brazil). Culture medium was autoclaved at $121^{\circ} \mathrm{C}$, for $20 \mathrm{~min}$, after $\mathrm{pH}$ adjusting to 5.8 .

\section{Seed disinfestation and aseptic culture establishment}

\section{a) Seed surface disinfestation with mercury chloride and water treatment}

Seeds were kept in flasks containing autoclaved distilled water for 24 or $48 \mathrm{~h}$, with a control treatment without water immersion. They were washed for $5 \mathrm{~min}$ in detergent and tap water and then rinsed 5 times in distilled water. In a laminar flow chamber, seeds were surface sterilized with ethanol $70 \%$ for $1 \mathrm{~min}$ and sodium hypochlorite $(\mathrm{NaOCl}) 10 \% \mathrm{w} / \mathrm{v}$ with $0.01 \%$ Tween $20^{\circledR}$ for $20 \mathrm{~min}$. Finally, they were treated with mercury chloride $\left(\mathrm{HgCl}_{2}\right)$ solutions at 0.1 or $0.2 \%$, for 4 or $8 \mathrm{~min}$, and then rinsed 6 times in autoclaved distilled water.

Seeds were individually inserted into test tubes $(15 \mathrm{~cm}$ high $\times 2.5 \mathrm{~cm}$ diameter), containing $10 \mathrm{~mL}$ of standard medium. The experimental design was completely randomized as a $3 \times 5$ factorial (water immersion $\mathrm{x}$ mercury treatments), with five replicates containing six seeds each. Contamination was evaluated one month after in vitro culture initiation.

\section{b) Fungicide added to culture medium}

The procedure was exactly the same as in the previous experiment. However, $0.5 \mathrm{~g} \mathrm{~L}^{-1}$ Cercobin $^{\circledR} 700 \mathrm{WP}$ (Iharabras S.A Indústrias Químicas, São Paulo State, Brazil), a systemic fungicide, was added to the culture medium.

\section{c)PРMTM treatment and water immersion}

Seeds were kept in Erlenmeyer flasks containing distilled autoclaved water or $2 \mathrm{~mL} \mathrm{~L}^{-1}$ plant preservative mixture $\left(\mathrm{PPM}^{\mathrm{TM}}\right.$, Plant Cell Technology, Washington, DC., USA) solution for 24 or $48 \mathrm{~h}$. The control seeds were not immerged in water. 
After treatments, seeds were washed with detergent for $5 \mathrm{~min}$ and in a laminar flow chamber their surface were sterilized with $70 \%$ ethanol ( $1 \mathrm{~min}$ ), followed by a $5 \%$ solution of $\mathrm{NaOCl}$ supplemented with $0.01 \%$ Tween $20^{\circledR}$ (Sigma-Aldrich, Saint Louis, Missouri, USA) for 20 min and finally $0.1 \% \mathrm{HgCl}_{2}(10 \mathrm{~min})$. Seeds were rinsed six times in distilled autoclaved water and individually inserted into test tubes containing $10 \mathrm{~mL}$ of culture medium.

Standard medium was supplemented with $1.5 \mathrm{~mL} \mathrm{~L}^{-1}$ or $2 \mathrm{~mL} \mathrm{~L}^{-1} \mathrm{PPM}^{\mathrm{TM}}$, plus a control treatment without this biocide. The experimental design was completely randomized as a $3 \times 5$ factorial $\left(\mathrm{PPM}^{\mathrm{TM}}\right.$ concentration in culture medium $\mathrm{x}$ imbibition treatments), with six replicates containing five seeds each. The seeds were maintained in the growth room. Contamination and survival rates in vitro culture were evaluated after 30 days.

\section{Effect of gibberellin on in vitro germination}

Seeds were kept in water or gibberellin $\left(\mathrm{GA}_{3}\right)$ solution $(2.89,5.77,14.43$ or $28.89 \mu \mathrm{M})$ for 24 or $48 \mathrm{~h}$. Seeds were surface-sterilized as in the experiment with PPM ${ }^{\mathrm{TM}}$ and introduced individually in test tubes containing sucrose-free standard medium. Seed germination was evaluated every two days for three months and data were utilized to determine the germination speed index (GSI).

The experimental design was completely randomized as a $2 \times 5$ factorial (exposure period $\mathrm{x} \mathrm{GA}_{3}$ concentration), with five replicates containing eight seeds each. The variables evaluated were: percentage of fungal and/or bacterial contamination, germination percentage, GSI and time required for the emergence of shoots. The GSI was calculated according to the equation proposed by Maguire (1962).

\section{Shoot multiplication}

Seedlings with 30 days after in vitro germination were used as donor of explants for multiplication phase. Nodal segments $(1.25 \pm 0.25 \mathrm{~cm})$ from the epicotyls, with two nodes each and without visible contamination, were transferred to standard medium supplemented with $1 \mathrm{~mL} \mathrm{~L}^{-1} \mathrm{PPM}^{\mathrm{TM}}, 1 \mathrm{~g} \mathrm{~L}^{-1}$ polyvinylpyrrolidone (PVP) and $8.8 \mu \mathrm{M}$ 6-benzylaminopurine (BA). Shoot apexes were discarded. The rest of the explant including the seed was transferred to glass bottles $(6 \mathrm{~cm}$ diameter $\mathrm{x}$ $8.5 \mathrm{~cm}$ height) containing a fresh standard medium without PGRs. To evaluate the resprout capability of in vitro seedlings, the plantletS with one node were maintained until new shoots resprout at the base that could be cut to repeat the process. Two explants were placed in each bottle containing $40 \mathrm{~mL}$ of culture medium, each closed with a polypropylene cap.

Explants were subculture at 30 days intervals, being transferred to identical fresh medium. The necrotic edges were excised and discarded and shoots longer than $3 \mathrm{~cm}$ were individualized each month. The multiplication step had duration of three months and the number of shoots per explant was evaluated each month.

\section{Culture conditions}

Seed germination was performed in a germination chamber at $25^{\circ} \mathrm{C}$, under a long day photoperiod $(16 \mathrm{~h})$ and fluorescent light. During multiplication, explants were maintained in a growth chamber at $20^{\circ} \mathrm{C}$ (night) and $26 \pm 1{ }^{\circ} \mathrm{C}$ (day), under a $16 \mathrm{~h}$ photoperiod and fluorescent light with photosynthetic photon flux density of about $30 \mu \mathrm{mol} \mathrm{m}{ }^{-2} \mathrm{~s}^{-1}$.

\section{Acclimatization}

The plantlets originated from seeds after several subcultures were transferred to pots containing substrate (Plantmax ${ }^{\circledR}$, Eucatex Agro-Florestal, São Paulo State, Brazil) and vermiculite (Dimy ${ }^{\circledR}$, Paraná State, Brazil) at a ratio of $1: 1$, in a greenhouse at $24^{\circ} \mathrm{C}$ and irrigated for 5 min every $6 \mathrm{~h}$. Their survival was evaluated after 180 days.

\section{Statistical analysis}

Data were submitted to Bartlett's test and analysis of variance (ANOVA), then to mean comparison by Tukey's test at 5\%. The statistical software used was Assistat 7.6 (Silva \& Azevedo, 2009).

\section{Results and discussion}

\section{Seed disinfestation and aseptic culture establishment}

a) Seed surface disinfestation with mercury chloride and water treatment

After 30 days of culture, the mean contamination rate of the experiment was $52 \%$ (Table 1), approximately half by fungi and half by bacteria. Statistical analysis indicated that water immersion and $\mathrm{HgCl}_{2}$ treatment did not affect fungal contamination or survival of seeds. 
Table 1. Percentage of Calophyllum brasiliense contaminationfree seeds, after a water immersion period and mercury chloride treatments $\left(\mathrm{HgCl}_{2}\right), 30$ days after in vitro incubation into plant growth regulators-free culture medium.

\begin{tabular}{ccccc}
\hline \multirow{2}{*}{$\mathrm{HgCl}_{2}$ treatment } & \multicolumn{4}{c}{ Contamination-free seeds (\%) } \\
\cline { 2 - 5 } & 0 & $24 \mathrm{~h}$ water & $48 \mathrm{~h}$ water & Mean \\
\hline Control & 70.0 & 40.0 & 36.6 & $48.8^{\mathrm{ns}}$ \\
$0.1 \% 4 \mathrm{~min}$ & 56.6 & 40.0 & 43.3 & $46.6^{\mathrm{ns}}$ \\
$0.1 \% 8 \mathrm{~min}$ & 60.0 & 70.0 & 53.3 & $61.1^{\mathrm{ns}}$ \\
$0.2 \% 4 \mathrm{~min}$ & 46.6 & 56.6 & 43.3 & $48.8^{\mathrm{ns}}$ \\
$0.2 \% 8 \mathrm{~min}$ & 66.6 & 46.6 & 60.0 & $57.7^{\mathrm{ns}}$ \\
\hline Mean & $60.0^{\mathrm{ns}}$ & $50.6^{\mathrm{ns}}$ & $47.3^{\mathrm{ns}}$ & 52.6 \\
\hline
\end{tabular}

ns. Not significant (Tukey's test, $p>0.05$ ).

Even though statistical analysis did not show significant differences, the number of contamination-free seeds after 60 days was higher in the control treatment, i.e. not imbibed. This may indicate that contamination increases as the seeds remain in water. Similar results were obtained for Calophyllum inophyllum (Thengane et al., 2006), indicating that keeping the seeds in water favors the appearance of contaminants. Thengane et al. (2006) showed that presoaking facilitated the leaching of phenolic compounds from seeds, preventing browning and hastening germination process. According to Bewley et al. (2013), as the seed absorbs water, the cell membranes lose the ability to retain solutes such as sugars, organic acids, proteins and ions and they are released. These may stimulate growth of fungi and bacteria, which can penetrate the seed, being a superficial disinfestation protocol unsuccessful.

There was no difference in bacterial contamination and survival between the two mercury chloride concentrations tested. Differences were observed only between the control and $\mathrm{HgCl}_{2}$ treatments (Table 2). This indicates that the use of $\mathrm{HgCl}_{2}$ is required to avoid bacterial contamination, and the lowest concentration is indicated. Fungal contamination was low and the incorporation of $\mathrm{HgCl}_{2}$ did not reduce the number of affected explants.

Table 2. Fungal and bacterial contamination in seeds of Calophyllum brasiliense, in function of the exposure time and mercury chloride $\left(\mathrm{HgCl}_{2}\right)$ concentration during surface disinfestation, 30 days after in vitro culture into WPM medium plus $0.5 \mathrm{~g} \mathrm{~L}^{-1}$ Cercobin $^{\circledR}$.

\begin{tabular}{|c|c|c|c|c|c|c|c|c|c|}
\hline \multirow{2}{*}{$\frac{\mathrm{HgCl}_{2}}{\text { concentration (\%) }}$} & \multicolumn{3}{|c|}{ Fungal contamination (\%) } & \multicolumn{3}{|c|}{ Bacterial contamination (\%) } & \multicolumn{3}{|c|}{ Contamination-free seeds $(\%)$} \\
\hline & $4 \mathrm{~min}$ & $8 \mathrm{~min}$ & Mean & $4 \mathrm{~min}$ & $8 \mathrm{~min}$ & Mean & $4 \min$ & $8 \mathrm{~min}$ & Mean \\
\hline Control & - & - & $7.8^{\mathrm{ns}}$ & - & - & $51.1 \mathrm{a}$ & - & - & $41.1 \mathrm{~b}$ \\
\hline 0.1 & 7.8 & 5.6 & $6.7^{\mathrm{ns}}$ & 41.1 & 27.8 & $34.4 \mathrm{~b}$ & 51.1 & 66.7 & $58.9 \mathrm{a}$ \\
\hline 0.2 & 5.6 & 5.6 & $5.6^{\mathrm{ns}}$ & 36.7 & 23.3 & $30.0 \mathrm{~b}$ & 57.8 & 71.1 & $64.4 \mathrm{a}$ \\
\hline Mean & $6.7^{\mathrm{ns}}$ & $5.6^{\mathrm{ns}}$ & 6.4 & $38.9 \mathrm{a}$ & $25.5 \mathrm{~b}$ & 36.0 & $54.4 \mathrm{a}$ & $68.9 \mathrm{~b}$ & 57.6 \\
\hline
\end{tabular}

Means followed by the same letter do not differ to the same variable (Tukey's test, $p \leq 0.05$ ). ns. Not significant ( $p>0.05$ ).

The longer the duration of exposure to mercury chloride for surface disinfestation, the lower the bacterial contamination and higher survival rates, although no differences were observed for fungal contamination.

The average germination rate was $12 \%$, with no interference of treatments (data not shown). Germination was considered very low, and plumule emergence was observed in only one of the seeds, even after 120 days of culture. The abnormal seeds, emitting only roots, can be explained by the excess of solutes in the culture medium, as happened in the case of maize (Bradford, 1994; Bewley et al., 2013). The presence of sucrose in the culture medium may have reduced their water potential, resulting in poor absorption of water by the seed, reducing the germination as the embryo suffers water stress (Bradford, 1994). According to Bewley et al. (2013), if water uptake is too slow, germination is reduced due to seed deterioration.

Moreover, sucrose is one of the main products of protein and lipid storage breakdown during seed germination and it is considered a regulatory agent, with signalizing functions (Rolland et al., 2006; Borek et al., 2012, 2013). A study of To et al. (2002) showed that mobilization of seed storage lipid by Arabidopsis thaliana was delayed in the presence of exogenous sugars, resulting in almost complete elimination of lipid breakdown, without interference of osmotic stress. Thus, important enzymes for storage lipid breakdown are more active in organs cultured in absence of sucrose (Borek et al., 2013). 


\section{a)Fungicide added to culture medium}

Cercobin ${ }^{\circledR}$ is a systemic fungicide. Its active compound is thiophanate methyl which combats fungal contamination due to the recognized property of its group, benzimidazoles, of preventing tubulin polymerization during metaphase, thereby causing inhibition of mitotic divisions and cell proliferation (García-Cela et al., 2012).

Average contamination of seeds in culture medium plus Cercobin ${ }^{\circledR}$ was $42 \%$ after 30 days, similar to that obtained in previous experiment without this product. Fungal contamination was only $6.4 \%$, showing the efficiency of this fungicide (Table 3). On the other hand, fungal contamination was increased when seeds were maintained in water for $48 \mathrm{~h}$.

Table 3. Fungal and bacterial contamination in seeds of Calophyllum brasiliense, after a water immersion period and surface disinfestation in ethanol, sodium hypochlorite and mercury chloride, 30 days after in vitro insertion into WPM medium plus $0.5 \mathrm{~g} \mathrm{~L}^{-1}$ Cercobin $^{\circledR}$.

\begin{tabular}{cccc}
\hline $\begin{array}{c}\text { Immersion } \\
\text { period (hours) }\end{array}$ & $\begin{array}{c}\text { Fungal } \\
\text { contamination (\%) }\end{array}$ & $\begin{array}{c}\text { Bacterial } \\
\text { contamination } \\
(\%)\end{array}$ & $\begin{array}{c}\text { Contamination-free } \\
\text { seeds (\%) }\end{array}$ \\
\hline Control & $3.3 \mathrm{a}$ & $32.7^{\mathrm{ns}}$ & $64.0^{\mathrm{ns}}$ \\
24 & $3.3 \mathrm{a}$ & $40.7^{\mathrm{ns}}$ & $56.0^{\mathrm{ns}}$ \\
48 & $12.7 \mathrm{~b}$ & $34.7^{\mathrm{ns}}$ & $52.7^{\mathrm{ns}}$ \\
\hline Mean & $6.4 \%$ & $36.0 \%$ & $57.5^{\circ} \%$ \\
\hline
\end{tabular}

Means followed by the same letter do not differ to the same variable (Tukey's test, $\mathrm{p} \leq 0.05)$. ${ }^{\mathrm{ns}}$. Not significant $(\mathrm{p}>0.05)$.
Bacterial contamination, however, was not affected by water immersion, but it increased if compared with experiment without Cercobin ${ }^{\circledR}$ (36\% compared to $24 \%$ ). This increase suggests that fungi might repress bacteria growth and, in the absence or reduction of fungal population, bacteria tend to multiply more easily in the culture medium.

Immersion period in water favored contamination of seeds through microorganism proliferation. Growth of fungi and bacteria can be stimulated by leakage of solutes that occurs during imbibition, such as sugars, organic acids, ions, amino acids, and proteins (Bewley et al., 2013).

The average germination rate of $C$. brasiliense seeds observed was $16 \%$ and it was not affected by the treatment used in surface disinfestation or by water immersion (data not shown). Only two seeds developed shoots, while the others only emitted roots, indicating abnormal seedling development, possibly due to water potential reduction (Bradford, 1994) or regulatory effects mediated by sucrose (Rolland et al., 2006; Borek et al., 2012, 2013)

\section{b) $\mathbf{P P M}^{\mathrm{TM}}$ treatment and water immersion}

After 30 days of culture, the mean contamination rate of seeds was $27 \%$, nearly half of that observed in the previous experiments with or without Cercobin ${ }^{\circledR}$. The use of $\mathrm{PPM}^{\mathrm{TM}}$ in culture medium reduced contamination (Table 4). Contamination rates were also affected by the solution in which the seeds were soaked (water or $\mathrm{PPM}^{\mathrm{TM}}$ ).

Table 4. Percentage of fungal and bacterial contamination, and contamination-free seeds of Calophyllum brasiliense, after immersion in $2 \mathrm{~mL} \mathrm{~L}^{-1}$ of plant preservative mixture $\left(\mathrm{PPM}^{\mathrm{TM}}\right)$ or water, and addition of different concentrations of $\mathrm{PPM}^{\mathrm{TM}}$ to plant growth regulator-free culture medium prior to autoclaving, 30 days after in vitro incubation.

\begin{tabular}{ccccc}
\hline \multirow{2}{*}{ Imbibition treatment } & \multicolumn{4}{c}{ Contamination-free seeds (\%) } \\
\cline { 2 - 5 } & $\mathbf{0}$ & $\mathbf{1 . 5} \mathbf{~ m L ~ L ~}^{\mathbf{- 1}} \mathbf{P P M}^{\mathbf{T M}}$ & $\mathbf{2} \mathbf{~ m L ~ L ~}^{\mathbf{- 1}} \mathbf{P P M}^{\mathbf{T M}}$ & Mean \\
\hline Control & 53.3 & 66.7 & 73.3 & $64.4 \mathrm{~b}$ \\
24h water & 63.3 & 86.7 & 76.7 & $75.6 \mathrm{ab}$ \\
24h PPM $^{\mathrm{TM}}$ & 60.0 & 76.7 & 73.3 & $70.0 \mathrm{ab}$ \\
48h water & 50.0 & 66.7 & 76.7 & $64.4 \mathrm{~b}$ \\
48h PPM & & 86.7 & 93.3 & $86.7 \mathrm{a}$ \\
\hline Mean & $61.3 \mathrm{~b}$ & $76.7 \mathrm{a}$ & $78.7 \mathrm{a}$ & 72.2 \\
\hline
\end{tabular}

Means followed by the same letter do not differ to the same variable (Tukey's test, $p \leq 0.05$ ). ${ }^{\text {ns. Not }}$ significant $(\mathrm{p}>0.05)$. 
The combination of fungicides and antibiotics to eliminate bacteria as well as fungi in the culture medium should be avoided because it tends to be inefficient and phytotoxic (Leifert et al., 1991). Thus, the use of PPM ${ }^{\mathrm{TM}}$ was effective and it may be recommended instead of addition of antibiotics to the culture medium.

Although germination rate reached almost 35\%, exceeding the results of the experiments using only mercury chloride or with Cercobin ${ }^{\circledR}$, the plumule emission was still low and occurred in less than $1 \%$ of the seeds (Fig. 1b), even 120 days after the in vitro introduction. This indicates that some aspects of the culture is not suitable for seeds germination and initial development of plantlets.

\section{Effect of gibberellin on in vitro germination}

Water or $\mathrm{GA}_{3}$ exposure for $48 \mathrm{~h}$ was harmful to seeds, reducing germination rate to $60 \%$ if compared with $72 \%$ for a $24 \mathrm{~h}$ immersion (Table 5). This exposure time negatively affected plumule emergence.

Table 5. Germination speed index (GSI), GSI for plumule emergence and germination percentage of Calophyllum brasiliense seeds, exposed to different concentrations of gibberellic acid $\left(\mathrm{GA}_{3}\right)$ or maintained in water for 24 or $48 \mathrm{~h}$ after in vitro culture in free-sucrose WPM medium.

\begin{tabular}{cccccccc}
\hline \multirow{2}{*}{\begin{tabular}{c}
$\mathrm{GA}_{3} \begin{array}{c}\text { concentration } \\
(\mu \mathrm{M})\end{array}$ \\
\cline { 2 - 8 }
\end{tabular}} & \multicolumn{2}{c}{ GSI (up to 60 days) } & \multicolumn{2}{c}{ Germination after 60 days (\%) } & \multicolumn{3}{c}{ GSI (plumule emergence) } \\
\cline { 2 - 8 } Control & $24 \mathrm{~h}$ & $48 \mathrm{~h}$ & $24 \mathrm{~h}$ & $48 \mathrm{~h}$ & $24 \mathrm{~h}$ & $48 \mathrm{~h}$ & Mean \\
2.89 & $0.217 \mathrm{aA}$ & $0.160 \mathrm{aA}$ & $77.5 \mathrm{aA}$ & $57.5 \mathrm{abB}$ & 0.265 & 0.184 & $0.224 \mathrm{ab}$ \\
5.77 & $0.084 \mathrm{bcA}$ & $0.153 \mathrm{aA}$ & $75.0 \mathrm{aA}$ & $42.5 \mathrm{bB}$ & 0.248 & 0.184 & $0.216 \mathrm{ab}$ \\
14.47 & $0.167 \mathrm{abA}$ & $0.069 \mathrm{abB}$ & $77.5 \mathrm{aA}$ & $70.0 \mathrm{aA}$ & 0.283 & 0.258 & $0.270 \mathrm{a}$ \\
28.89 & $0.150 \mathrm{abA}$ & $0.069 \mathrm{abB}$ & $80.0 \mathrm{aA}$ & $67.5 \mathrm{aA}$ & 0.294 & 0.244 & $0.269 \mathrm{a}$ \\
\hline Mean & $0.027 \mathrm{cA}$ & $0.011 \mathrm{bA}$ & $50.0 \mathrm{bA}$ & $62.5 \mathrm{abA}$ & 0.183 & 0.167 & $0.175 \mathrm{~b}$ \\
\hline
\end{tabular}

Means followed by the same lower letter in column, and capital letter in row, do not differ to the same variable (Tukey's test, $p \leq 0.05$ ). ns. Not significant $(\mathrm{p}>0.05)$.

Plumule emergence started at day 6 after treatment with $5.77 \mu \mathrm{M} \mathrm{GA}_{3}$. However, no radicle was observed in several cases, particularly with the higher doses of gibberellin, even 90 days after in vitro introduction. This suggests some type of inhibition caused by an increase in regulator concentration (Figure 1c-d).

The GSI was reduced as the duration of $\mathrm{GA}_{3}$ treatment increased $(p<0.05)$, and the treatment of $28.89 \mu \mathrm{M}$ showed statistical difference if compared to other treatments. At this concentration, there was inhibition of root protrusion and plumule emergence, and seed germination rate was reduced. This fact can indicate that this regulator causes phytotoxic effects in cases of prolonged exposure of seeds or high concentrations, as observed for seeds of Capparis ovata (Soyler \& Khawar, 2007), Securidaca longipedunculata (Zulu et al., 2011) and Capparis spinosa (Arefi et al., 2012). For Cicer arietinum, the optimal concentration of gibberellin for germination was $6 \mu \mathrm{M}$ (Kaur et al., 1998).

Gibberellin action during embryo development is linked to increased oxygen uptake by seeds and stimulated production of hydrolytic enzymes that degrade the aleurone layer present in the seeds, releasing sugars and peptides that allow germination (Paleg, 1960; Briggs, 1963; Bewley et al., 2013). With increase in respiration caused by gibberellin, it is likely that immersion in water reduces the availability of oxygen to the point at which the seeds are irretrievably damaged and lose the ability to germinate. Excess water under anaerobic conditions is harmful to the seed and, under anoxia conditions, seeds accumulate ethanol and lactic acid produced during fermentation (Bewley et al., 2013). Furthermore, $\mathrm{GA}_{3}$ tends to inhibit the formation of roots (Brian et al., 1960; Moshkov et al., 2008) as observed in the present study (data not shown).

Sucrose, absent in the culture medium but present in previous experiments, may affect germination. It reduces the water potential of culture medium, The total amount of water provided to the seeds is restricted, hindering imbibition and subsequent germination (Bewley et al., 2013). For Cereus jamacaru seed germination the concentration of $2.5 \mathrm{mg} \mathrm{L}^{-1}$ in the medium was more effective than higher concentrations (Rêgo et al., 2009).

Germination rates were up to $80 \%$, with no effect caused by treatment with gibberellic acid. This value is much higher than those obtained in previous experiments 
and is comparable to the germination rates of the species in nursery (Marques \& Joly, 2000; Silva et al., 2014) and forest environment (King, 2003). However, in vitro germination is advantageous for seedling rescue, as mean survival and establishment of seedlings in natural conditions is low (37\%) and affected by light, flooding and high herbivory pressure (King, 2003). In vitro germination can be associated to a breeding program for propagation of elite seeds, which could be further clonally propagated by in vitro multiplication. The plantlets originated from seeds were acclimatized in a greenhouse with approximately $90 \%$ survival.

\section{Shoot multiplication}

Seedlings maintained in the culture medium were sectioned and used as explants for multiplication phase. They quickly resprouted and the nodal segments could be individualized at intervals of 2 weeks to one month
(Figure 1e). From a single germinated seed, new nodal segments were cut up to 3 times without loss of regrowth capacity, and then the size of seedlings prevented their culture in vitro. This resprout capacity was also reported in natural environment by King (2003), with up to 18 resprouts in a single plant after suffering grazing. For C. inophyllum cultured in a medium containing plant growth regulators, up to 20 shoots were obtained from decapitated seedling after 60 days (Thengane et al., 2006).

After 30 days in culture medium containing $8.8 \mu \mathrm{M}$ $\mathrm{BA}$, the average number of shoots per segment nodal was 2. After 60 and 90 days, it was 2.7 and 3.4, respectively. Shoots developed directly, without callus formation (Figure 1f). These multiplication rates are close to those found for C. apetalum. For this species, the maximum number of shoots obtained from nodal segments of a mature tree was 3.2 after 6 weeks (Nair \& Seeni, 2003).
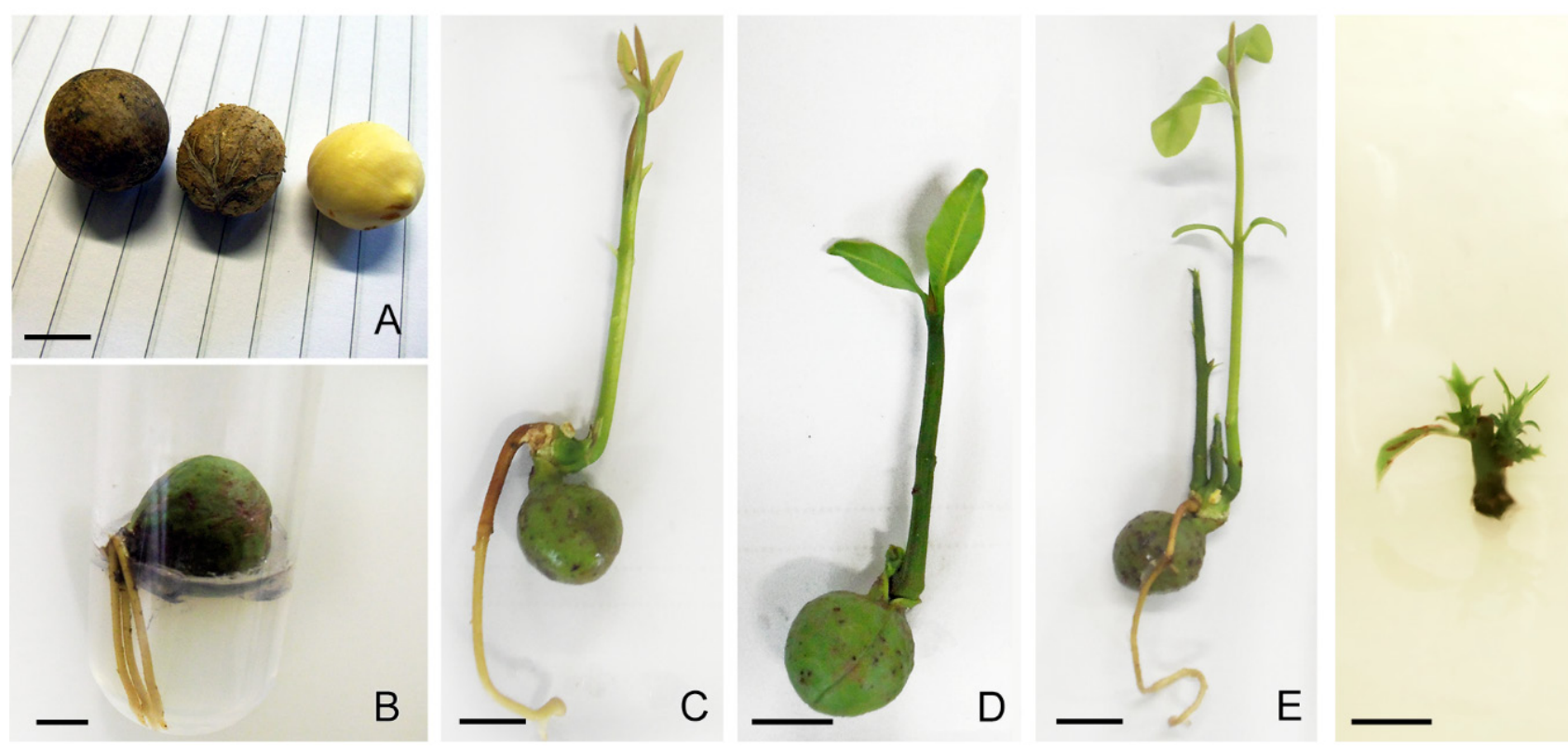

Figure 1. Seeds of Calophyllum brasiliense, respectively, with endocarp; endocarp-free and with tegument; tegument-free (as introduced in vitro) (a); germinated seed in WPM with $30 \mathrm{~g} \mathrm{~L}^{-1}$ sucrose, forming only roots (b); in sucrose-free medium, without $\mathrm{GA}_{3}$ application (c); in sucrose-free medium with $5.77 \mu \mathrm{m} \mathrm{GA}_{3}$, rootless $(\mathrm{d})$; showing three resprouts that were used as explants for multiplication, the tallest one with 30 days (e); nodal segment after 30 days in culture medium containing 8.8 $\mu \mathrm{M}$ BA (f). Bar: $1 \mathrm{~cm}$.

\section{Conclusions}

Germination of guanandi seeds in vitro is possible although time consuming and expensive. It is recommended the immersion of seeds in $0.2 \%$ solution of plant preservative mixture ( $\left.\mathrm{PPM}^{\mathrm{TM}}\right)$ for $24 \mathrm{~h}$ before surface disinfestation. The use of PGR-free and sucrosefree WPM is indicated for seeds introduction, with addition of $1.5 \mathrm{~mL} \mathrm{~L}^{-1} \mathrm{PPM}^{\mathrm{TM}}$.

Gibberellic acid accelerates the emission of shoots up to a concentration of $14 \mu \mathrm{M}$ but inhibits it above that concentration. The higher the concentration of $\mathrm{GA}_{3}$ 
used, the smaller the number of plants that emit roots at this stage. $\mathrm{GA}_{3}$ may therefore be added in a higher concentration if the aim of the study is to obtain only shoots.

Multiplication rates of shoots excised from seedlings were close to those obtained for other species of Calophyllum genus. Moreover, seedlings maintained in vitro had a high ability to sprout again, and this may be an alternative for obtaining plants on a large scale.

\section{Acknowledgements}

The authors are grateful to Douglas Steinmacher for revising the manuscript and Eileen Bagyary for editing it. We thank Coordenação de Aperfeiçoamento de Pessoal de Nível Superior (CAPES) for financial support to the first author.

\section{References}

Arefi, I. H. et al. Roles of duration and concentration of priming agents on dormancy breaking and germination of caper (Capparis spinosa L.) for the protection of arid degraded areas. Pakistan Journal of Botany, v. 44, n. esp., p. 225-230, 2012.

Bernabé-Antonio, A. et al. Production of anti-HIV-1 calanolides in a callus culture of Calophyllum brasiliense (Cambes). Plant Cell, Tissue and Organ Culture, v. 103, p. 33-40, 2010. DOI: 10.1007/ s11240-010-9750-4.

Bewley, J. D. et al. Seeds: physiology of development, germination and dormancy. 3rd ed. New York: Springer, 2013.

Borek, S. et al. Diverse regulation by sucrose of enzymes involved in storage lipid breakdown in germinating lupin seeds. Acta Physiologiae Plantarum, v. 35, p. 2147-2156, 2013. DOI: 10.1007/ s11738-013-1251-8.

Borek, S. et al. Regulation by sucrose of storage compounds breakdown in germination seeds of yellow lupine (Lupinus luteus L.), white lupine (Lupinus albus L.) and Andean lupine (Lupinus mutabilis Sweet). II. Mobilization of storage lipid. Acta Physiologiae Plantarum, v. 34, p. 1199-1206, 2012. DOI: 10.1007/s11738-0110916-4.

Bradford, K. J. Water stress and the water relations of seed development: a critical review. Crop Science, v. 34, n. 1, p. 1-11, 1994.

Brian, P. W. et al. Inhibition of rooting of cuttings by gibberellic acid. Annals of Botany, v. 24, n. 96, p. 407-419, 1960.

Briggs, D. E. Biochemistry of barley germination action of gibberellic acid on barley endosperm. Journal of the Institute of Brewing, v. 69, p. 13-19, 1963.

Cole, R. J. et al. Direct seeding of late-successional trees to restore tropical montane forest. Forest Ecology and Management, v. 261, p. 1590-1597, 2011. DOI: 10.1016/j.foreco.2010.06.038.
Fischer, E. \& Santos, F. A. M. Demography, phenology and sex of Calophyllum brasiliense (Clusiaceae) trees in the Atlantic. Journal of Tropical Ecology, v. 17, p. 903-909, 2001.

García-Cela, E. et al. Effect of preharvest anti-fungal compounds on Aspergillus steynii and A. carbonarius under fluctuating and extreme environmental conditions. International Journal of Food Microbiology, v. 159, p. 167-176, 2012. DOI: 10.1016/j. ijfoodmicro.2012.08.001.

Huerta-Reyes, M. et al. HIV-1 inhibitory compounds from Calophyllum brasiliense leaves. Biological and Pharmaceutical Bulletin, v. 27, n. 9, p. 1471-1475, 2004.

Ito, C. et al. Chemical constituents of Calophyllum brasiliensis: structure elucidation of seven new xanthones and their cancer chemopreventive activity. Journal of Natural Products, v. 65, n. 3, p. 267-272, 2002. DOI: 10.1021/np010398s.

Kaur, S. et al. Gibberellic acid and kinetin partially reverse the effect of water stress on germination and seedling growth in chickpea. Plant Growth Regulation, v. 25, p. 29-33, 1998.

King, R. Succession and micro-elevation effects on seedling establishment of Calophyllum brasiliense Camb. (Clusiaceae) in an Amazonian river meander forest. Biotropica, v. 35, n. 4, p. 462-471, 2003. DOI: 10.1111/j.1744-7429.2003.tb00603.x.

Leifert, C. et al. Contaminants of plant-tissue and cell cultures. World Journal of Microbiology and Biotechnology, v. 7, p. 452-469, 1991.

Lloyd, G. \& Mccown, B. H. Commercially feasible micropropagation of mountain laurel (Kalmia latifolia) by use of shoot tip culture. International Plant Propagation, v. 30, p. 421-427, 1980.

Maguire, J. D. Speed of germination - aid in selection and evaluation for seedling emergence and vigor. Crop Science, v. 2, p. 176-177, 1962.

Marques, M. C. M. \& Joly, C. A. Seed germination and growth of Calophyllum brasiliense (Clusiaceae), a typical species of flooded forests. Acta Botanica Brasilica, v. 14, n.1, p. 113-120, 2000. DOI: 10.1590/S0102-33062000000100010.

Mng'Omba, S. A. et al. Efficacy and utilization of fungicides and other antibiotics for aseptic plant cultures. In: Dhanasekaran, D. et al. (Ed.). Fungicides for plant and animal diseases. InTech: JanezaTrdine, 2011. p. 245-254.

Moshkov, I. E. et al. Plant growth regulators III: Gibberellins, ethylene, abscisic acid, their analogues and inhibitors; miscellaneous compounds. In: George, E. F. et al. (Ed.). Plant Propagation by tissue culture. Dordrecht: Springer, 2008. v.1. p. 227-283.

Nair, L. G. \& Seeni, S. In vitro multiplication of Calophyllum apetalum (Clusiaceae), an endemic medicinal tree of the Western Ghats. Plant Cell, Tissue and Organ Culture, v. 78, p. 169-174, 2003. DOI:10.1023/A:1025001214995.

Newstrom, I. E. et al. A new classification for plant phenology based on flowering patterns in lowland tropical forest trees at La Selva, Costa Rica. Biotropica, v. 26, p. 141-159, 1994. DOI: 10.2307/2388804.

Oliveira, V. C. \& Joly, C. A. Flooding tolerance of Calophyllum brasiliense Camb. (Clusiaceae): morphological, physiological and growth responses. Trees, v. 24, p. 185-193, 2010. DOI: 10.1007/ s00468-009-0392-2. 
Paleg, L. G. Physiological effects of gibberellic acid: I. on carbohydrate metabolism and amylase activity of barley endosperm. Plant Physiology, v. 35, n. 3, p. 293-299, 1960.

Rêgo, M. M. et al. In vitro seed germination of mandacaru (Cereus jamacaru DC.). Revista Caatinga, v. 22, n. 4, p. 34-38, 2009.

Rolland, F. et al. Sugar sensing and signaling in plants: conserved and novel mechanisms. Annual Review of Plant Biology, v. 57, p. 675-709, 2006. DOI: 10.1146/annurev.arplant.57.032905.105441.

Silva, F. de A. S. e. \& Azevedo, C. A. V. de. Principal components analysis in the software assistat-statistical attendance. In: WORLD CONGRESS OF COMPUTERS IN AGRICULTURE AND NATURAL RESOURCES, 7., 2009, Reno. Proceedings... St. Joseph: American Society of Agricultural and Biological Engineers, 2009.

Silva, R. C. da et al. Técnicas para superação de dormência de sementes de guanandi. Pesquisa Agropecuária Brasileira, v. 49, n. 9, 2014. DOI: 10.1590/S0100-204X2014000900008.
Souza, M. C. et al. In vitro and in vivo anti-Heliobacter pylori activity of Calophyllum brasiliense Camb. Journal of Ethnopharmacology, v. 123, p. 452-458, 2009. DOI: 10.1016/j.jep.2009.03.030.

Soyler, D. \& Khawar, K. M. Seed germination of caper (Capparis ovata var. Herbacea) using $\alpha$ naphthalene acetic acid and gibberellic acid. International Journal of Agriculture \& Biology, v. 9, n. 1, p. 35-37, 2007.

Thengane, S. R. et al. Micropropagation of Indian laurel (Calophyllum inophyllum), a source of anti-HIV compounds. Current Science, v. 90, n. 10, p. 1393-1397, 2006.

To, J. P. C. et al. Mobilization of seed storage lipid by Arabidopsis seedlings is retarded in the presence of exogenous sugars. BMC Plant Biology, v. 2, p. 4-15, 2002. DOI: 10.1186/1471-2229-2-4.

Zulu, D. et al. Propagation of the African medicinal and pesticidal plant, Securidaca longepedunculata. African Journal of Biotechnology, v. 10, n. 32, p. 5988-5992, 2011. 
